\title{
Hispanic Immigration and Spanish Maintenance as Indirect Measures of Ethnicity: Reality and Perceptions
}

\author{
Shaw N. Gynan \\ Western Washington University
}

\begin{abstract}
Many supporters of official English have accused U. S. Hispanics of refusing to learn English and rejecting the traditional assimilationist model by clinging to their ethnolinguistic identity. An analysis of U. S. Census data from the last thirty years refutes these claims. The picture of U. S. Hispanic maintenance of ethnolinguistic identity has evolved. Here we show that while adult Spanish loyalty has decreased, youth Spanish loyalty has increased; however, Spanish maintenance does not occur at the expense of English proficiency. Once recent immigrants are subtracted from the Hispanic population, U. S. Census figures show clearly that long-term limited English proficiency has decreased substantially. This analysis clearly supports the conclusions of experts who have noted that Hispanic youth are embracing a bilingual model, one which allows them to maintain their ethnolinguistic identity while acquiring the English skills necessary for success in the United States.
\end{abstract}

\section{INTRODUCTION}

The last three decades have seen an impressive rise in the rate of Hispanic immigration to the U.S. Many Americans question whether Hispanics are now maintaining their language to the exclusion of English. ${ }^{1}$ This concern about language is symbolic of fears that a politically and culturally separatist mentality is developing among U.S. Hispanics.

While the rate of Hispanic immigration to the U.S. remained relatively steady during the sixties and seventies, during the eighties the rate of immigration doubled (see Table 1). A series of events conspired to drive Hispanics to the U.S. in search of economic and political refuge. Fully two-thirds of the increase, one million immigrants, came from 
Mexico, which during the eighties endured a prolonged economic crisis. Political upheavals in Guatemala, El Salvador, Nicaragua, and Columbia added another 330,000 . Poverty and war were therefore largely responsible for the historic increase in the number of U.S. Spanish speakers.

The popular press has publicized polls that convincingly demonstrate that Americans on the whole have become increasingly hostile to immigration. Whereas in 1965 a Gallup poll found that only 33\% surveyed agreed that immigration to the U.S. should be decreased, that figure climbed to $42 \%$ in 1977 . A Times/CBS poll conducted in 1986 registered another increase in hostility to immigration to $49 \%$, and a poll conducted June $21-24,1993$ of 1,363 people recorded that $61 \%$ favored decreasing immigration. ${ }^{2}$ Individuals who derive their sense of self-worth from what they perceive to be the stability of the society in which they live feel threatened and less sure of themselves as they witness changes. The shifting status of English is the source of a considerable level of anxiety, which surely has been exacerbated by the high levels of speakers of "foreign" languages in the U.S.

In the literature on ethnicity self-recognition by a collectivity is accomplished in a partly contrastive way, that is, by defining one's group as separate from another. ${ }^{3} \mathrm{~A}$ change in public language use heightens the consciousness of an ethnic group of the boundary between its own identity and that of another group. In the case of the U.S., many monolingual Anglophones increasingly come into contact with speakers of other languages and become more aware of who they are as a group and at the same time become fearful of their future.

Certain politicians and lobbyists have tried to work the fear of change and heightened sense of ethnic boundaries to their advantage. Perhaps the best-known of these is Pat Buchanan, who in 1984 specifically linked the immigration question with issues both racial and linguistic when he stated "The central objection to the present flood of illegals is that they are not English-speaking white people from Western Europe; they are Spanish-speaking brown and black people from Mexico, Latin America, and the Caribbean." ${ }^{n 4}$

Another group that responds to and purports to represent the fears of Americans that Hispanics in particular represent a serious threat to the ethnolinguistic integrity of the U.S. is U.S. ENGLISH, an organization of over half a million which has been analyzed extensively in sociolinguistic literature. ${ }^{5}$ The claims published by U.S. ENGLISH that U.S. Hispanics are refusing to learn English are examined in the present article in light of data produced in academic research and by the U.S. Bureau of the Census. The purpose of this analysis is to use little understood sociolinguistic aspects of national U.S. English-Spanish bilingualism to refute incontrovertibly the claims of many official English boosters but at the same time to reveal the dynamic effect of change in languauage use on ethnolinguistic identity. 
Table 1

Hispanic Immigration to the U. S., 1960-1990

(not included: Bolivia, Paraguay, Uruguay)

Census Year

\begin{tabular}{|c|c|c|c|}
\hline Country & $1961-1970$ & $1971-1980$ & $1981-1990$ \\
\hline Spain & 30,500 & 30,000 & 15,800 \\
\hline Mexico & 443,300 & 637,200 & $1,653,300$ \\
\hline Cuba & 256,800 & 276,800 & 159,200 \\
\hline Dominican Republic & 94,100 & 148,000 & 251,800 \\
\hline Costa Rica & 17,400 & 12,100 & 15,500 \\
\hline El Salvador & 15,000 & 34,400 & 214,600 \\
\hline Guatemala & 15,400 & 25,600 & 87,900 \\
\hline Honduras & 15,500 & 17,200 & 49,500 \\
\hline Nicaragua & 10,100 & 13,000 & 44,100 \\
\hline Panamá & 18,400 & 22,700 & 29,000 \\
\hline Argentina & 42,100 & 25,100 & 25,700 \\
\hline Chile & 11,500 & 17,600 & 23,400 \\
\hline Colombia & 70,300 & 77,600 & 124,400 \\
\hline Ecuador & 37,000 & 50,200 & 56,000 \\
\hline Perú & 18,600 & 22,700 & 41,300 \\
\hline Venezuela & 8,500 & 7,100 & 17,100 \\
\hline TOTALS & $1,104,500$ & $1,408,300$ & $2,799,400$ \\
\hline
\end{tabular}




\section{Ethnolinguistic Identity}

The sociolinguistic dimension of U.S. Hispanic bilingualism is relevant to the larger question of ethnic identity, but the analysis of census data presented here is specifically related to language use and not to ethnicity per se. The task of determining just how the very revealing facts of immigrant and non-immigrant Spanish and English language use in the U.S. may be related to the larger sociocultural and political questions of ethnic identity is left to future research.

Ethnolinguistic identity is not entirely dependent on language use, and, conversely, use of a given language is not necessarily indicative of a certain ethnic identity; however, the term itself strongly implies a relationship between the two. ${ }^{6}$ A U.S. Hispanic who speaks no Spanish is probably not the same ethnically as another U.S. Hispanic for whom Spanish is a native language. Native knowledge of a language does not confer a certain kind of ethnicity, a fact evident to some Chicano exchange students during their stays in Mexico, during which they discover how very different they are from Mexicans. ${ }^{7}$ Nevertheless, the U.S. Spanish-speaker who first travels to a Spanish-speaking country frequently experiences a rediscovery of aspects of his or her ethnicity of which he or she was previously unaware.

The U.S. Hispanic community is very diverse but is responded to politically as a unitary entity by some politicians, by lobbying concerns such as the 500,000 member U.S. ENGLISH organization, and by many Americans. Political postures reflect, albeit imperfectly, popular sentiment, and popular sentiment, in turn, is relevant to the question of ethnicity, since the phenomenon is not merely a function of a group's view of itself but of how outsiders view the group as well. ${ }^{8}$

A revealing example of the fear of the rise of Spanish is cited in the pages of U.S. ENGLISH, which quotes John Hughes, a Pulitzer Prizewinning journalist who was Assistant Secretary of State from 1982 to 1984:

Spanish is a second language for many, the sole language for some. The 1980 census indicated that 23 million Americans do not speak English at home; by the year $\mathbf{2 0 0 0}$ the total number of non-English-speaking Americans will be just under 40 million. Nobody questions their right to maintain the language and culture of their ancestry, or the desirability of doing so. What language people speak at their own dinner tables is no business of government. ${ }^{9}$

Hughes may have meant simply that there will be $\mathbf{4 0}$ million individuals whose first language is other than English, but note the hyperbole that 
both explicitly and implicitly is present in his prediction: people whose first language is not English are not English speakers. As we shall see, that assertion is simply not supported by the facts.

While it is important to recognize that ethnicity and language are only indirectly related and that in certain areas of the U.S. the influence of immigration is felt much more than others, Hispanic maintenance of ethnolinguistic identity is viewed in this article as a national phenomenon, evidence for which is limited to self-evaluations of U.S. Hispanics reported to the U.S. Bureau of the Census. This is entirely appropriate, since the paper is essentially a response to those politicians and constituent groups who claim that the putative shift away from English and toward Spanish is a phenomenon national in scope.

\section{The Context of U.S. Hispanic Language Behavior}

In 1990 , of the $230,445,777$ persons in the U.S. who were age five or over, $31,844,979$ spoke a language other than English at home (see Table 2). Of these, $13,982,502$, or approximately $6 \%$ of the U.S. population reported not speaking English at the level 'very well.' The census bureau reports that over $75 \%$ of nonnative English speakers claim to speak English at least "well."11 This means that of the 32 million non-native speakers of English slightly fewer than eight million or 3.5\% reported speaking English less than "well." Even someone who reports that his or her English is only "fair" hardly can be considered to be a nonEnglish-speaker, so this method of determining acceptable English proficiency is conservative. Nonetheless, even using this conservative estimate, $96.5 \%$ of the country speaks English "weli" or "very well."

\section{Table 2}

Summary Statistics on Language Use from 1990 U.S. Census (Persons 5 years and over: 230,445,777) ${ }^{10}$

$\begin{array}{lccc}\begin{array}{c}\text { Mother tongue of } \\ \text { U.S. citizens } 5 \text { years } \\ \text { and over who speak } \\ \text { a language other than } \\ \text { English }\end{array} & \begin{array}{c}\text { Number of U.S. } \\ \text { citizens } 5 \text { years and } \\ \text { over who speak a } \\ \text { language other than } \\ \text { English }\end{array} & \begin{array}{c}\text { Number of U.S. } \\ \text { citizens } 5 \text { years and } \\ \text { over who do not } \\ \text { speak English } \\ \text { 'very well' }\end{array} & \begin{array}{c}\text { Percent who do } \\ \text { not speak English } \\ \text { very well' }\end{array} \\ \text { Asian/Pacific } & 17,345,064 & 8,309,995 & 47.9 \% \\ \text { TOTAL } & 4,471,621 & 2,420,355 & 54.1 \% \\ & 31,844,979 & 13,982,502 & 43.9 \%\end{array}$


Within this national context the figures in Table 2 show that while the proportion of U.S. Hispanics who report speaking English "very well" is somewhat higher than that of the total population of non-Englishmother-tongue Americans, a higher proportion of the U.S. population of Asian/Pacific origin is of limited English proficiency (as defined by this overly conservative method). The figures in Table 2 also reveal that although speakers of many other languages were also living in and immigrating to the U.S., speakers of Spanish constituted the overwhelming majority of individuals claiming a language other than English as their mother tongue.

\section{The Increase in the Number of U.S. Spanish Speakers}

During the life of U.S. ENGLISH, Spanish, the world's third or fourth largest language depending on how such matters are figured, has also grown tremendously in the U.S. ${ }^{13}$ The growth of Spanish in the U.S. is a complex phenomenon. Millions of people are involved, which makes precise quantification a daunting task. What is more, this historic demographic shift must be examined not only in absolute terms, but as well in relation to the broader patterns of U.S. population growth. Bills, Hernández-Chávez and Hudson have refined a number of relevant measures which simplify the job of understanding language shift. ${ }^{14}$ The most basic and easily understood is "count," which is simply the total number of individuals in a given group. In Table 3 the U.S. and U.S. Hispanic counts are presented. The figures are indeed striking. The historic increase in the numbers of U.S. Hispanics that occurred during the last decade was actually eclipsed in some respects by the increase in Hispanics during the seventies, which alerted the supporters of official English to the perceived challenge that their language faced.

In 1970, the total U.S. population was $203,302,031$, and Hispanic density, defined by Bills, Hernández-Chávez and Hudson as the proportion of the population that is of Hispanic origin, stood at only $3.9 \%$ (see Table 3). Just over $12 \%$ of those Hispanics had immigrated to the U.S. during the previous decade. By 1980, of the total U.S. population of $226,545,580,6.4 \%$ was Hispanic. The Hispanic population had increased by $5,536,017$ to $14,608,673$.

The data on the increase in the U.S. Hispanic count may be analyzed in greater detail in order to allow for a more complete understanding of this important demographic shift of the seventies (see Table 4). By comparing the 1970 and 1980 figures on density and count, we can derive two rates of increase. The first is an increase in Hispanic count, calculated by expressing the difference between the 1980 and 1970 figures as a proportion of the 1970 count: $14,608,673-9,072,602) /$ $9,072,602=.61$. Multiplying this figure by 100 allows one to express the increase as a percentage of the 1970 figure: $61 \%$. The rate of increase 
in Hispanic count dropped to $50 \%$ in the next decade. A second rate of increase is in what Bills, Hernández-Chávez, Hudson, refer to as "density," that is, the percentage of the entire population that is Hispanic (see density figures in Table 3). The rate of increase in Hispanic density from 1970 to 1980 was $64 \%$. During the next decade the rate of increase was much less at $38 \%$.

\section{Table 3}

\section{U.S. Hispanic Count and Density, 1970-199012}

$\begin{array}{ccccccc}\begin{array}{c}\text { Census } \\ \text { Year }\end{array} & \begin{array}{c}\text { U.S. Count } \\ \text { (USC) }\end{array} & \begin{array}{c}\text { Hispanic Count } \\ \text { (HC) }\end{array} & \begin{array}{c}\text { Hispanic } \\ \text { Density }\end{array} & \begin{array}{c}\text { Hispanic } \\ \text { Immigrant }\end{array} & \begin{array}{c}\text { Hispanic } \\ \text { Immigrant }\end{array} \\ 1970 & 203,302,031 & 9,072,602 & 3.9 \% & 1,104,500 & 0.5 \% \\ 1980 & 226,545,580 & 14,608,673 & 6.4 \% & 1,408,300 & 0.6 \% \\ 1990 & 248,709,873 & 21,900,089 & 8.8 \% & 2,799,400 & 1.1 \%\end{array}$

Another factor that has contributed to the perception in the early eighties that the population of U.S. Hispanics, especially Spanish-speaking Hispanics, was increasing rapidly, was the tremendous influx of immigrants to the U.S. In 1970 only $0.5 \%$ of the U.S. population had migrated from Hispanic countries during the previous decade (this is labeled Hispanic Immigrant Density in Table 3). In 1980, $0.6 \%$ of the U.S. population had migrated from Hispanic countries. Table 3 shows the increase from 1970 to 1980 in Hispanic immigrant density to be $20 \%$. Certainly this increase was even more noticeable in border states.

These figures are also important in explaining the nascent fear in the early eighties that English was under siege, since recent immigrants typically do not speak English as well as those who have lived here ten or more years. During the eighties the increase in Hispanic immigrant count and density was even more dramatic and lends further support to the idea that the increased linguistic evidence of Hispanic presence fueled the anti-immigrant and English-only movements of the eighties. What is especially remarkable about the data in Table 4 is the large difference between Hispanic and Hispanic immigrant rates of increase. Whereas the rate of increase in total Hispanic count and density dropped, the rate of increase in Hispanic immigrant count and density rose. To the casual observer the effect was a notable increase in the use of Spanish in the U.S. during the seventies and especially during the eighties. 


\section{Table 4}

Rates of Increase in U.S. Hispanic and Hispanic Immigrant Count and Density, 1970-1990.

Census Year Hispanic Count Hispanic Hispanic Hispanic Density Immigrant Immigrant Count Density

$1970-1980$

$61 \%$

$64 \%$

$28 \%$

$20 \%$

$1980-1990$

$50 \%$

$38 \%$

$99 \%$

$83 \%$

\section{The Increase in the Number of Spanish-Speakers}

The above analysis of the effect of rising Hispanic and Hispanic immigrant count and density shows the basis of some of the fears of those associated with U.S. ENGLISH, but an important question has been left unanswered. Are U.S. Hispanics clinging to their mother tongue? Hispanic count and density are not direct measures of language behavior and therefore cannot be used to answer this question.

Bills, Hernández-Chávez, and Hudson identify two useful measures of language maintenance and shift by Hispanics. They include "loyalty," the proportion of a group that is Spanish speaking, and "retention," the ratio of youth loyalty to adult loyalty. Data on loyalty and retention based on U.S. census data are presented in Table 5. These measures can be used to present a more accurate picture of maintenance of Spanish in the U.S. A glance at Table 5 will reveal that among young and old Hispanics alike, the vast majority report using Spanish. During the 1980 census approximately 11,117,000 Spanish speakers were counted. This figure was later revised upward to $11,549,000$. Of these individuals a total of $2,952,000$ aged $5-17$ spoke Spanish. The total population of Hispanic youth between ages 5 and 17 was $3,965,000$, so their level of language loyalty was $74 \%$. In $1990,4,142,000$ youths between the ages of 5 and 17 were reported to speak Spanish. Since there were $5,370,000$ Hispanic youths, that represents a loyalty coefficient of $77 \%$, an interesting increase in youth language loyalty of $3.6 \%$ but hardly the massive shift fears expressed repeatedly in U.S. ENGLISH Update. ${ }^{15}$

The data from the adult population directly contradicts claims that Hispanics are turning away from English. In 1980 out of a total of $8,981,000$ U. S. Hispanic adults ( 18 and older), $8,164,000$ spoke Spanish, a language loyalty rate of $91 \%$. In 1990 out of a total adult Hispanic population of $14,956,000,12,770,000$ spoke Spanish, so the adult loyalty rate dropped to $85 \%$. The figures in Table 5 show that the rate of retention (referred to on the chart as "youth/adult loyalty") of Spanish 
has actually increased by just over $10 \%$. Since retention is the ratio of youth loyalty to adult loyalty, the increase to a large extent is due to the decrease in adult loyalty, which makes retention by the younger generation appear all the more striking. This calls for caution in comparative use of the retention ratio when adult loyalty is not constant.

\section{U.S. Hispanic Ability in English}

Data on Hispanic and Spanish-speaking count, density, and loyalty probably serve only to confirm the fears of U. S. ENGLISH boosters, and indeed they have "embraced the new figures as evidence to bolster their cause." ${ }^{16}$ The statistics welcomed by U. S. ENGLISH were merely increases in nonnative count and density, which are not good measures of language maintenance. ${ }^{17}$ Even measures of language maintenance do not provide an adequate response to what is perhaps the most ardent claim by supporters of official English: that Spanish speakers have stopped learning English.

\section{Table 5}

Changes in U.S. Hispanic and Spanish Speaker Count, Loyalty, and Retention, 1980-1990

Census Year

Total Hispanic Count 5 years old and over

Total Spanish Speaker Count 5 years old and over

Total Language Loyalty

Hispanic Count 5-17 years

Spanish Speaker Count 5-17 years

Youth Language Loyalty

Hispanic Count 18 years old and over

Spanish Speaker Count 18 years old and over

Adult Language Loyalty

Youth/Adult Loyalty Ratio
1980 1990

$12,946,000$

$20,326,000$

$11,117,000$

$16,912,000$

.86 .83

$3,965,000$

$5,370,000$

$2,952,000$

$4,142,000$

.74

.77

$8,981,000 \quad 14,956,000$

$8,164,000 \quad 12,770,000$

.91

.85

.81 
In order to answer the question of U.S. limited English proficiency (LEP), 1980 data are analyzed first (see Table 6). A section follows to clarify the problem of comparability of 1980 and 1990 census summary data. Finally, 1990 data are analyzed and compared with those of 1980. Data on the issue of Hispanic ability in English are displayed in Table 6.

\section{Table 6}

Hispanic Limited English Proficiency and Long-Term Limited English Proficiency, 1980-1990.

Census Year

1980

1990

Rate of

Increase
Total U.S. Count

Total Hispanic Count

Total Spanish-Speaking Hispanic Count

Non-Immigrant Spanish-Speaking Hispanic Count

Total Immigrant Count

Total Hispanic LEP Count

LEP Density among All Hispanic

Spanish-Speakers

LEP Density among All Hispanics

Spanish-Speaking LEP Density in U.S. Population

Total Spanish-Speaking LTLEP

Count

LTLEP Density among NonImmigrant Spanish-Speaking Hispanics

LTLEP Density among All Hispanics

Spanish-Speaking LTLEP Density among All U.S. Population

$\begin{array}{rrr}226,546,00 & 248,710,000 & 10 \% \\ 14,609,000 & 21,900,000 & 50 \% \\ 11,117,000 & 16,912,000 & 52 \%\end{array}$

$9,709,000 \quad 14,113,000 \quad 70 \%$

$1,408,000 \quad 2,799,000 \quad 99 \%$

$2,708,000 \quad 4,228,000 \quad 56 \%$

.24

.25

$5 \%$

.18

.19

$6 \%$

.01

.02

$100 \%$

$1,300,000 \quad 1,537,000 \quad 18 \%$

.13

.11

$-15 \%$

.09

.07

$-22 \%$

.0057

.0062

$9 \%$ 


\section{Hispanic Limited English Proficiency in 1980}

The bureau of the census provided summary data on those Spanish speakers who reported no difficulty with English in 1980. Of the $14,609,000$ Hispanics, approximately $11,117,000$ age five and older reported speaking Spanish, and 2,708,000 (24\% of Spanish speakers, $18 \%$ of all Hispanics, and $1 \%$ of the U.S. population) reported difficulty with English. During the previous decade, approximately 1,408,000 Hispanics had immigrated to the U.S. Assuming that recently immigrated Hispanics have difficulty with English, by subtracting the number of recent immigrants from the total number of LEP Hispanics, a core of $1,300,000$ long-term LEP (LTLEP) speakers of Spanish can be identified. To the extent that the assumption concerning the English ability of immigrants is wrong, the number of enduring monolingual Spanish speakers could be even greater. The procedure establishes a minimum limit to the count of LTLEP, the occurrence of which may be due to linguistic isolation, economic marginalization, lack of motivation, or lack of educational opportunity.

Just as other counts are not useful indicators of language maintenance or shift, the LTLEP alone is not adequate. Three indices of LTLEP density need to be derived. The number of non-immigrant Spanish-speaking Hispanics is derived simply by subtracting the number of immigrants from the Spanish-speaking Hispanic total. Dividing the LTLEP count by this figure, we obtain an index of LTLEP density among non-immigrant Spanish-speaking Hispanics of $13 \%$. This is an important figure, for it responds to the fear that supporters of official English had in the early eighties that those who had lived for an extended period of time in the U.S. and persisted in using Spanish were rejecting English. That fear is simply unfounded. Of long-term U.S. Hispanic residents, $87 \%$ have no problem whatsoever with English. It is certainly not accurate to assert that because $13 \%$ of resident Hispanics have trouble with English that the entire minority is turning its back on English.

Critics of the U.S. Hispanic presence almost unfailingly refers to all Hispanics without distinguishing on the basis of ability in Spanish, so it is appropriate that an index of LTLEP density among all Hispanics should be calculated. As can be seen in Table 6, the result is .09 or nine\%. This figure takes into account the fact that many Hispanics do not speak any Spanish at all, a fact that certainly is not emphasized by those who whip up fear against Spanish-speakers and their descendents.

Finally, since critics of bilingualism constantly publicize the putative threat that the Hispanic refusal to learn English represents to national unity, it is important to calculate the proportion of U.S. citizens who are Spanish-speaking LTLEP. The 1.3 million LTLEP Spanish-speakers in 1980 represented just under $.06 \%$ of the American population. 
This, plus the newly arrived immigrants, in concrete, demographic terms, was the size of the linguistic threat from Spanish-speakers that was faced in the U.S. in the early nineties.

\section{The Comparability of 1980 and 1990 Census Summaries}

Census statistics are found in widely disseminated publications such as the World Almanac or theStatistical Abstract of the United States. Since the 1980 summary described Hispanic ability in English in terms of "reporting no difficulty with English," and the 1990 summary described Hispanic ability in English in terms of "not speaking English 'very well,"' the general impression caused is that Hispanic ability in English has declined over the last decade.

It is now all too easy to confuse two very different statements about language ability. U.S. citizens in 1990 were asked to locate their language ability along a dimension ranging from "very poor" to "very well." The $38 \%$ of Hispanics who did not choose the category 'very well' did not necessarily rate themselves as "very poor," "poor" or even "fair" (refer again to Table 2). In fact, as noted above, according to Barringer the Bureau of the Census reports that when the category "well" is added, the number of English speakers among non-native Americans jumps to $75 \%$. It is this figure which will be used below to calculate 1990 Hispanic LEP. The problems of comparability notwithstanding, a reasonable procedure can be formulated to determine in a future study the extent to which Hispanics and others who have been in the U.S. for a decade or more continue to be limited in English proficiency (LEP).

Using the census estimate that $75 \%$ of nonnative speakers of English speak the language "well" or "very well," we can assume conservatively that $4,228,000$ of the $16,912,000$ Spanish-speaking Hispanics were LEP in 1990 . Note that this figure is only roughly comparable with the 1980 census summary statistics which reported ability in terms of having no difficulty. Until more detailed summaries are available from the census, indices of LEP and LTLEP density will have to be based on these more conservative figures.

\section{Hispanic Limited English Proficiency in 1990}

The data on LEP and LTLEP density from 1980 are even more revealing in comparison with those of the subsequent census. In 1990 as shown in Table 6, 21,900,000 of the total U.S. population of 248,710,000 were Hispanic. The 4,228,000 Hispanics who in 1990 reported speaking English less than "very well" or "well" represented only a slight increase in LEP among Hispanics (6\%); however, in the U.S. the increase in LEP Hispanics jumped $100 \%$. 
The huge increase in Spanish LEP as a percentage of the U.S. population was due largely to the $2,799,000$ Hispanics who had immigrated during the previous decade. When this figure is subtracted from the LEP count, only $1,537,000$ Hispanics are LTLEP. This represents an $18 \%$ increase over the LTLEP count from the previous decade. Reiterating the limited usefulness of count for determining language maintenance and shift, we turn to the figures on LTLEP density. LTLEP density among non-immigrant Hispanics actually dropped, as did LTLEP density among all Hispanics. Whereas LEP increased $100 \%$ in the U.S. as a whole, LTLEP increased only $9 \%$.

\section{Attitudinal Shift in Language Loyalty}

One may wonder how Americans could be so worried about the imagined Hispanic refusal to learn English when in fact the percentage of LTLEP Hispanics dropped by $15 \%$. The statistical analysis of the census above reveals two facts especially germane to the issue of U.S. ENGLISH perceptions of sociolinguistic reality. The first fact that emerges from the census analysis that explains the perception that Hispanics and other ethnic minorities are shifting languages is the striking difference between adult and youth language loyalty evident from Table 5. This interesting attitudinal change was reported in the New York Times to be documented in a study of 5,000 eighth and ninth grade children of immigrants by Johns Hopkins sociologist Alejandro Portes who discovered high ratings of self-proficiency in English among Mexican-Americans and Cuban-Americans ( $85 \%$ and $99 \%$, respectively)..$^{18}$ These figures for Mexican-American children, in fact, correspond nearly exactly to the 1980 census data that indicated that $85 \%$ of Hispanic youth reported "no difficulty with English." ${ }^{19}$ These figures indicate that there has been no shift away from English. What is interesting in this context is that Portes makes the striking discovery in his study that $56 \%$ of the Mexican-American children prefer Spanish over English, despite their high level of English proficiency.

Hakuta and D'Andrea demonstrate that language shift among youngsters is a robust phenomenon, even in a linguistically isolated Hispanic enclave in Northern California. This directly refutes Tanton's assertion that such isolation leads to Spanish maintenance and failure to learn English. English proficiency among Hispanic youth is a function of age of arrival to the U.S., time of residence in the U.S., and whether parents were born in Mexico or the U.S. Language attitude does not predict proficiency but significantly does predict language choice, in other words, what language a young person will use with peers, siblings, or adults. ${ }^{20}$ Solé's study of Southwest U.S. census statistics is one of several that confirm significant language shift among Mexican-American youth. ${ }^{21}$ 
Proponents of U.S. ENGLISH are quite right in perceiving an attitudinal shift. It is evident in public places. Children in particular no longer feel that they must throw away their mother tongue in order to succeed in the U.S. Portes interprets this change to mean that the old model of assimilation has been debunked. Hakuta and D'Andrea's study, as well as census statistics, shows that a positive attitude toward Spanish does not affect proficiency in English but rather how their proficiency in Spanish is viewed and whether they will choose to use Spanish when the opportunity presents itself. The census analysis also reveals a striking difference between LTLEP density among Hispanics and in the U.S. as a whole. The impressive progress in English by Hispanics resident in the U.S. for ten years or longer has been completely overshadowed by the historic increase in Hispanic immigrants.

While it is true that in cities having a higher proportion of recent immigrants there are also higher rates of retention of Spanish, ${ }^{22}$ high rates of immigration (see Table 1) of Hispanics have not caused LTLEP density to increase. On the contrary, the vast majority of Hispanics continue to acquire English to a high degree of proficiency. This fact is testimony to the fact that Hispanics do leam English well, in stark contrast to what has been implied and claimed for years in U.S. ENGLISH Update.

\section{CONCLUSION}

Immigration has had a marked effect on the U.S. community as a whole. What is more, the number of Spanish speakers during the last decade increased dramatically, by $50 \%$. An accompanying effect has been a change in the attitude of U.S. high school children toward their own ethnolinguistic identity (see Sontag's 1993 reference to the Portes study). Hispanic and other ethnic minority youth are less willing to accept an assimilationist model that requires them to abandon their ethnolinguistic identity as the price to pay for full participation in American society.

While the rise in the use of Spanish is obvious to many, the casual observer cannot easily ascertain Hispanic English ability. The census shows the vast majority of all Hispanics speak English well. Adult Hispanic loyalty towards Spanish has actually dropped and the proportion of Hispanics of limited English proficiency has decreased.

Organizations and movements which promote and defend bilingualism must understand the facts of U.S. bilingualism in order to counter baseless claims that the Hispanic community in particular is becoming more and more ethnolinguistically separatist. Explaining the truth of language maintenance and shift is no easy task, since the numbers are very large and the argumentation somewhat technical. That data that show indisputably that nearly all Hispanics leam English well must be publicized. Otherwise, the positive youthful attitude toward ethnolinguistic 
identity will be unfairly interpreted as rebellious and will strengthen the backlash against bilingualism.

\section{NOTES}

${ }^{1}$ For an analysis of the U.S. ENGLISH organization's campaign against ethnolinguistic diversity in the U.S., see Shaw N. Gynan, "An Analysis of Attitudes toward Spanish as Expressed in US ENGLISH Update," Southwest Journal of Linguistics 12 (1993), 1- 38.

${ }^{2}$ Seth Mydans, "A new tide of immigration brings hostility to the surface, poll finds," New York Times, 27 June 1993, section 1, 1, 16.

${ }^{3}$ See Joshua A. Fishman, Language and Ethnicity in Minority Sociolinguistic Perspective (Clevedon, England: Multilingual Matters, 1989), 33.

${ }^{4}$ Buchanan's comments are quoted in Jonathan Alter and Michael Isikoff, "The Beltway Populist." Newsweek 127 (4 March 1996): 24-27.

${ }^{5}$ See for example Thomas S. Donahue, “'U.S. ENGLISH': Its life and works," International Journal of the Sociology of Language 56 (1985): 99-112; David F. Marshall, "The question of an official language: language rights and the English language amendment,"International Journal of the Sociology of Language 60 (1986): 7-75; Joshua A. Fishman, "English only': Its ghosts, myths, and dangers," International Journal of the Sociology of Language 74 (1988):125-140; James Crawford's brief but revealing history of the organization in Bilingual Education: History, Politics, Theory and Practice (Trenton, NJ: Crane Publishing Co., 1989), 54-58; and yet another interesting set of details of the group's ties to anti-immigrationist causes in Raymond Tatalovich, Nativism Reborn?: The Official English Language Movement and the American States (Lexington, KY: The University Press of Kentucky, 1995), 10-16.

'See Fishman, 1988, 32; refer also to Howard Giles and Patricia Johnson, "Ethnolinguistic identity theory: A social psychological approach to language maintenance," International Journal of the Sociology of Language 68 (1987): 69-99.

${ }^{7}$ For a frank and memorable chronicle of one such voyage of discovery, see Erlinda Gonzales-Berry, Paletitas de Guayaba (Albuquerque NM: Academia/El Norte Publications,1991).

${ }^{8}$ Fishman, 1988, 24. 
9 John Hughes, "For US, it's English," Christian Science Monitor, 28 June 1985, reprint Update 3 (4), 3.

10U.S. Bureau of the Census, "1990 Census of population and housing summary tape file $3 C^{n}$ (Washington, DC: U.S. Government Printing Office, 1993).

${ }^{11} F$ elicity Barringer, "For 32 million Americans, English is a second language," New York Times, 28 April 1993, A18. Barringer reports revised 1980 census figures of $11,549,000$, but since the figures on difficulty with English reported by the census bureau are based on the original data, the slightly lower figures are followed throughout this article.

${ }^{12}$ Data for all charts are taken from reports by the U.S. Bureau of the Census, 1960 census of population. General social and economic characteristics: United States summary (Washington DC: U.S. Government Printing Office, 1962); 1970 census of population. National origin and language (Washington DC: U.S. Govemment Printing Office, 1975); Statistical abstract of the United States: 1980. 106 ${ }^{\text {th }}$ Edition (Washington, D.C.: U.S. Government Printing Office, 1985); and "1990 Census of population and housing summary tape file $3 C^{n}$ (Washington, D.C.: U.S. Government Printing Office, 1993).

${ }^{13}$ Sydney Culbert, "The World's Languages," in The World Almanac and Book of Facts (New York NY: Pharos, 1994), 578-79.

${ }^{14}$ Garland D. Bills, Eduardo Hernández-Chávez and Alan Hudson,. "The geography of language shift: Distance from the Mexican border and Spanish language claiming in the Southwestem United States," University of New Mexico Working Papers in Linguistics 1 (1993): 15-30.

${ }^{15}$ For an example, refer to former U.S. ENGLISH director John Tanton's editorial, "Things are different now," Update 3 (1985): 6.

${ }^{16}$ Barringer, A18.

17Bills, et al., 23.

${ }^{18}$ Data from the study by Portes are reported by Deborah Sontag, "A fervent ' $n o$ ' to assimilation in new America: children of immigrants rewriting an axiom," New York Times, 29 June 1993, A10.

${ }^{19}$ See Shaw N. Gynan, "La nueva política lingüística en los Estados Unidos: Propósitos y motivos," in Language and Language Use: Studies in Spanish, ed. Terrell. A. Morgan, James F. Lee, and Bill. VanPatten (Lanham, MD: University Press of America, 1987), 182. 
${ }^{20}$ Kenji Hakuta, and Daniel D'Andrea, "Some properties of bilingual maintenance and loss in Mexican background high-school students," Applied Linguistics 13 (1992): 72-73.

${ }^{21}$ Yolanda R. Solé, "Bilingualism: stable or transitional? The case of Spanish in the United States," International Journal of the Sociology of Language 84 (1990): 35-80.

${ }^{22}$ Bills, et al., 26.

Shaw N. Gynan (Ph. D. in Ibero-Romance Philology and Linguistics, University of Texas Austin 1983) is Professor of Spanish and Linguistics at Western Washington University. Gynan's specialization is the sociolinguistic context of second language acquisition, and his work has appeared or is forthcoming in Hispania, The Modern Language Journal, Southwest Journal of Linguistics, and Hispanic Linguistics. Gynan recently received a Fulbright Senior Scholar award to lecture and conduct research in Paraguay, where he studied the situation of national bilingualism. 